\title{
Pulmonary infiltrates and abdominal colic pain in a patient with a connective tissue disorder
}

\author{
G Herrero-Beaumont, O Sánchez-Pernaute, J C Acebes
}

\begin{abstract}
Case report
A 32 year old white women was admitted to our hospital complaining of long term fever and fatigue. She reported recurrent episodes of fever lasting 7 to 10 days accompanied by joint pain and weakness during the past four months. Subsequently she developed a productive cough and pleuritic chest pain on the right side. She had not travelled recently or been exposed to contagious diseases. She had not noticed any skin lesions, but on specific questioning reported photosensitivity and Raynaud's phenomenon. She had a history of several lung infections and urolithiasis. She had had two normal deliveries and no miscarriages. There was a family history of interstitial lung disease.
\end{abstract}

On admission she was febrile $\left(37.8^{\circ} \mathrm{C}\right)$. Physical examination revealed a conjunctival injection and bilateral submandibular lymph nodes. Wheezes were audible in the right lung base. Cardiac auscultation and abdominal palpation were unremarkable. Joint examination showed tenderness of proximal interphalangeal joints.

Laboratory data included the following: erythrocytes $4.75 \times 10^{12} / 1$, haemoglobin $128 \mathrm{~g} / 1$, platelets $200 \times 19^{9} / 1$, leucocytes $6.8 \times 10^{9} / 1$ and erythrocyte sedimentation rate (ESR) $70 \mathrm{~mm}$ $1 \mathrm{st}$ h. Serum biochemistry: creatinine 110 $\mu \mathrm{mol} / 1$ (normal range 60-110), calcium 2.42 $\mathrm{mmol} / 1(2.1-2.5)$ and phosphorous $0.69 \mathrm{mmol} /$ 1.(0.97-1.45). Urine density was $1010, \mathrm{pH} 7$ and there were 12-20 erythrocytes/high magnification field and amorphous carbonates in the sediment. Immunoglobulins: IgG 22 g/1 (816), IgA $2.23 \mathrm{~g} / 1$ (1-3), IgM $1.24 \mathrm{~g} / 1$ (0.8-2.5). Results were negative for HIV, Epstein-Barr serology, tuberculin test and direct examination of acid-alcohol resistant mycobacteria in sputum.

A chest radiograph showed bilateral interstitial infiltrates at the lung bases (fig 1) and thoracic computed tomography confirmed the lesions (fig 2). Bronchial lavage cultures demonstrated a growth of an ampicillin resistant Haemophilus influenzae. She was given cefotaxime, $2 \mathrm{~g}$ three times daily.

During admission she developed an acute episode of abdominal pain accompanied by hypotension and vomitting. Plain radiographs (fig 3) showed multiple calcifications in both renal silhouettes. Urograms revealed a func- tional loss of the left kidney (fig 4) and ultrasonography disclosed a moderate hydronephrosis, which was reversed after extracorporeal lithotricy. A 24 hour urine analysis demonstrated hyperuricosuria $(47.6 \mathrm{mmol} / 24$ h), alkaline $\mathrm{pH}$ and hypocitraturia of $72 \mathrm{mg} / 24$ h (normal range $>320 \mathrm{mg} / 24 \mathrm{~h}$ ), with normal oxalate and calcium concentration. Plasma bicarbonate was $18 \mathrm{mmol} / 1$.

Despite prolonged antimicrobial treatment with resolution of chest abnormalities the fever persisted and synovitis appeared in proximal interphalangeal joints. Rheumatoid factor as determined by nephelometry was $300 \mathrm{IU} / \mathrm{ml}$ (normal below 40), and $\mathrm{C}$ reactive protein was $4.8 \mathrm{~g} / 1$ (normal below 1.0). Serological markers of viral hepatitis were negative. ANA were negative by immunofluorescence in Hep- 2 cells and complement proteins were normal: C3 98 g/1 (80-140), C4 $31 \mathrm{~g} / 1$ (12-33) and B factor 37 g/1 (22-48). Immunodiffusion demonstrated antibodies to the nuclear extractable antigens Ro and La. Schirmer's test was markedly diminished $(1 \mathrm{~mm}$ after 10 minutes in both eyes). Thyroid stimulating hormone (200

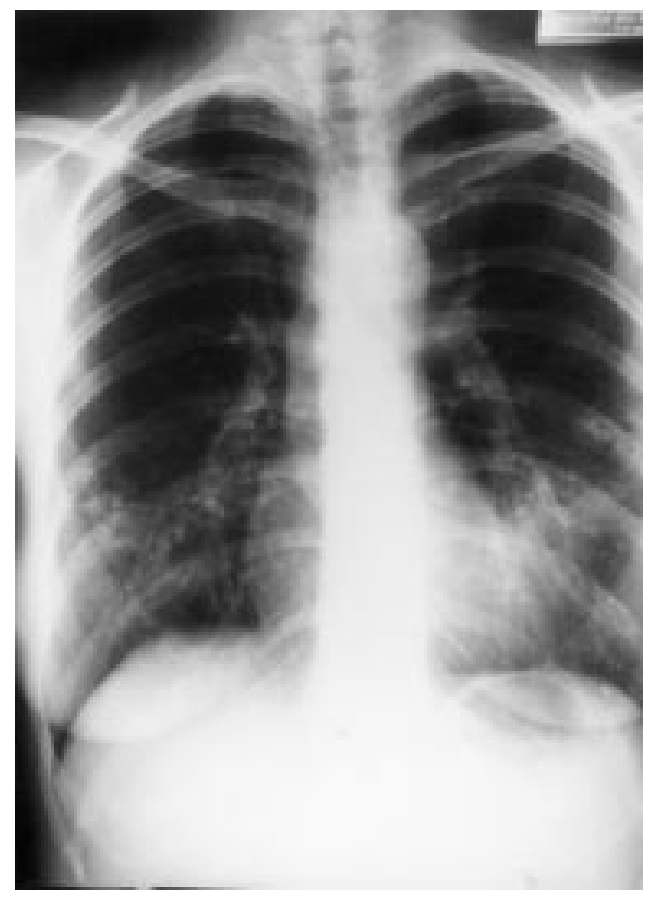

Figure 1 Chest radiograph of the patient on admission. Bilateral interstitial infiltrates at the lung bases are evident. 


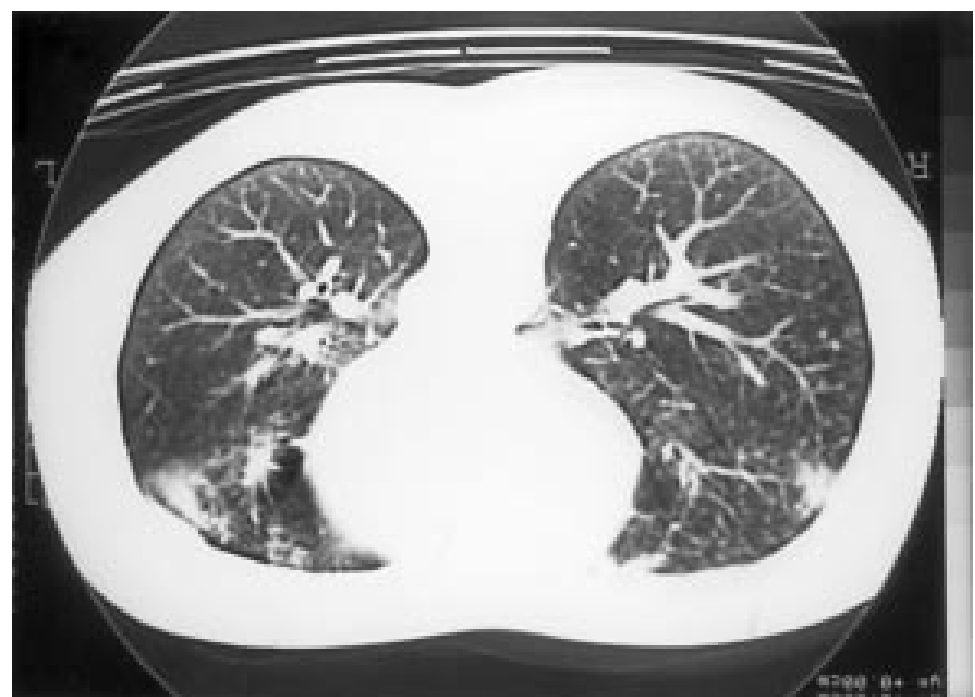

Figure 2 Pulmonary computed tomography shows multiple subpleural infiltrates. There are no changes in the surrounding parenchyma or adenopathies.

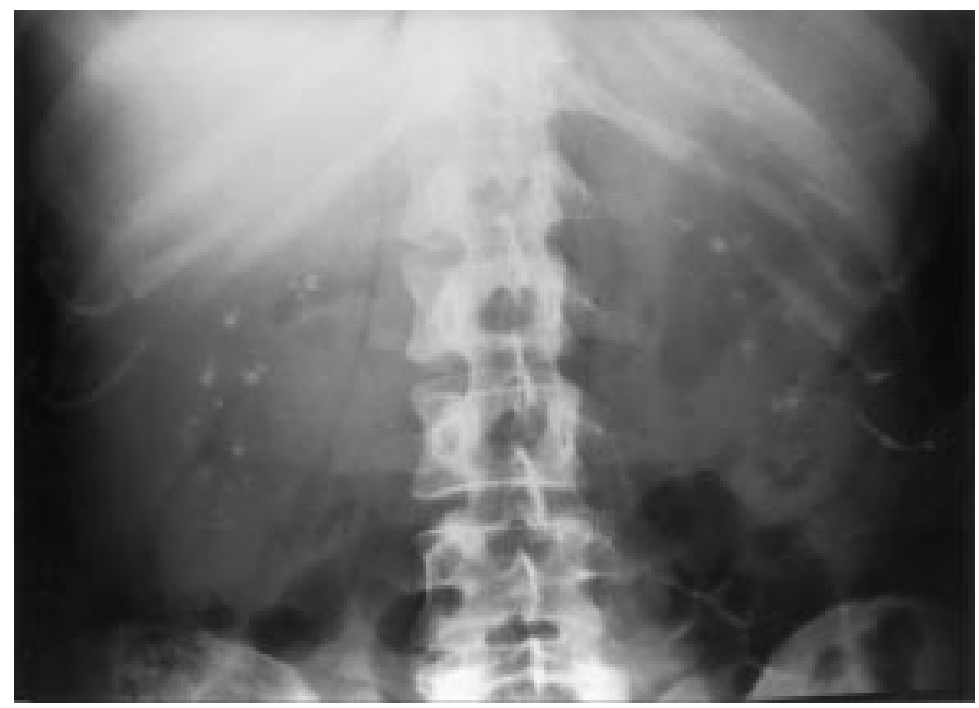

Figure 3 Plain abdominal radiograph film at the moment of the colic episode shows visible renal silhouettes plus multiple calcified images superposed to papillae.

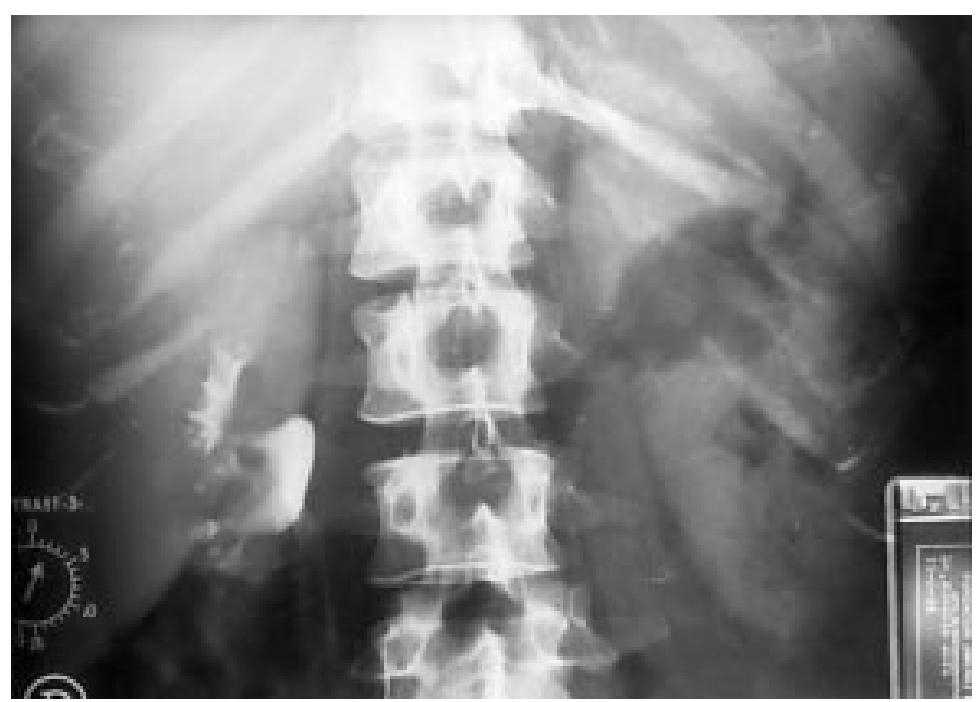

Figure 4 Urograms show absence of filtration by the left kidney five minutes after intravenous injection of the contrast. $\mu \mathrm{UI} / \mathrm{l})$ and free thyroxine $(12 \mathrm{ng} / \mathrm{l})$ were in normal range. A labial salivary gland biopsy showed inflammatory infiltration of the tissue yielding a lymphocytic focus score of $>1.0$ per $4 \mathrm{~mm}^{21}$ (fig 5).

The final diagnosis was primary Sjögren's syndrome (SS), interstitial pneumonia attributable to $H$ influenzae and urolithiasis favoured by distal renal tubular acidosis. The patient was discharged prescribed non-steroidal antiinflammatory drugs (NSAIDs) and citrates.

During follow up the patient continued to complain of asthenia and joint pain, with recurrent episodes of arthritis, and maintained an ESR persistently raised. As NSAID treatment failed to obtain symptomatic relief deflazacort was introduced at low doses. At about this time she developed an enlargement of the right parotid gland, but surprisingly did not complain of dryness. Despite continuous treatment with citrate she had several renal colic episodes, ending up in medullospongyosis and nephrocalcinosis, with slight impairment of renal function. She had a pregnancy and delivered a premature baby who had a complete atrioventricular block requiring a pacemaker.

\section{Discussion}

DIAGNOSTIC DIFFICULTIES IN SS

It is not unusual for a rheumatologist to be consulted on a case of fever, joint pain and malaise, while the patient actually has an infectious disease, such as a bronchopneumonia. Besides, patients with connective tissue disorders are predisposed to infections, and this should be borne in mind. The cluster of symptoms presented by our patient suggested initially either a bacterial pneumonia or tuberculosis, the latter being highly prevalent in Spain. However, the onset of symmetric proximal interphalangeal joint arthritis prompted us to search for a connective tissue disorder. Viral arthritis and hypothyroidism were also considered, as they are common causes of mild joint inflammation and fatigue. In fact, thyroid function should be examined in SS patients with extreme tiredness, ${ }^{2}$ because autoimmune thyroiditis has been reported in up to $10 \%$ of SS patients. ${ }^{3}$ The diagnosis of primary SS was established after demonstrating exocrine involvement by Schirmer's test and salivary gland histopathology together with a suggestive autoimmune profile.

SS is an autoimmune disease characterised by xerostomia and keratoconjunctivitis sicca (KCS). Although it is the most common connective tissue inflammatory disease, ${ }^{45}$ patients are correctly diagnosed on average 10 years after the onset of the disease, and usually after several medical consultations. ${ }^{6}$

The typical SS patient is a woman (female/ male ratio being 9 to 1 ) who presents with insidious symptoms and later develops manifestations of exocrine impairment, which make the condition easily recognised. However, there are patients who show features of generalised autoimmune disease, and only further studies reveal a subclinical exocrine involvement. Finally, the most challenging situation in diag- 

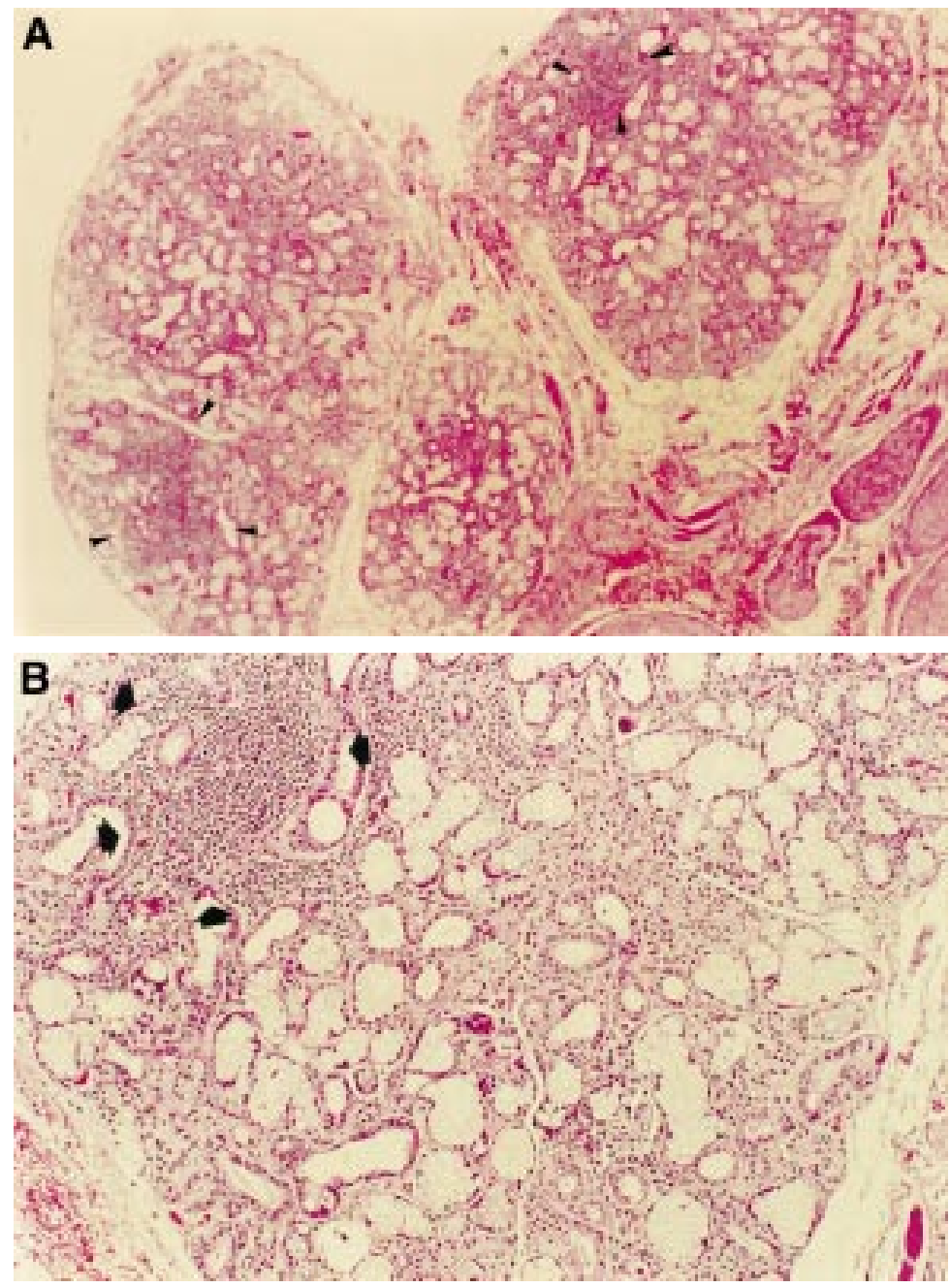

Figure 5 Labial salivary gland biopsy. (A) Arrowheads mark two lymphocytic foci within the salivary parenchyma (haematoxylin and eosin; original magnification $\times 40$ ). (B) View of a focal lymphocytic infiltrate (arrows) with preservation of the glandular architecture (haematoxylin and eosin; original magnification $\times 100$ ).

nostic terms occurs in patients presenting with parenchymal internal organ disease without obvious surface exocrine disease. ${ }^{7}$ Indeed, a wide variety of onset forms have been described in SS (table 1). Raynaud's phenomenon, cytopenic events, pulmonary disease and synovitis are the most common non-diagnostic associated features, while muscular, hepatobiliary or renal involvement are less frequent. ${ }^{11}$ Our patient illustrates the latter situation as she presented with sequential lung and renal involvement, which are considered as exocrine internal organ complications of SS, preceding any symptoms of xerostomia and KCS. This particular course of the disease was responsible for a delay in diagnosis.

Table 1 Clinical onset forms in SS others than sicca syndrome ${ }^{8-10}$

Thyroiditis Oligo/Polyarthritis Cutaneous vasculitis Polyneuritis

Haematological cytopenia Tiredness and fatigue Intermittent fever with hyperglobulinaemia Miscellaneous
DIFFERENTIAL DIAGNOSIS

SS and systemic lupus erythematosus (SLE) are diseases that share many pathological and serological features and may therefore be difficult to distinguish. Although photosensitivity is a characteristic of lupus, the absence of other typical manifestations of SLE in addition to the negativity of anti-DNA antibodies excluded the diagnosis of SLE with secondary SS. These two conditions may also overlap resulting in a

\section{Key messages}

- Systemic onset of SS without evident xerostomia or KCS must be considered in the differential diagnosis of inflammatory connective tissue disorders.

- Tubular acidosis complications such as hypokaliaemia, urolithiasis, nephrocalcinosis, and even osteomalacia can be avoided by a preventive treatment with daily lifelong alkali replacement.

disease known as the anti-La syndrome, which is identified by this serological marker. The anti-La syndrome could account for the patient's symptoms, including distal tubular acidosis, but the typical rash and marked hypergammaglobulinaemia of the overlap syndrome were not evident in this case. ${ }^{12}$

Additionally, conditions able to produce exocrine gland enlargement were ruled out by histopathology. These include granulomatous diseases such as sarcoidosis, deposition of amyloid or lipids, necrosis attributable to abnormal proteolitic activation, and neoplastic invasion, currently in cases of mucouse associated lymphoma.

\section{PULMONARY DISEASE}

The percentage of reported cases of lung involvement in SS varies widely reaching 30\% or even $55 \%$ in some series. ${ }^{13}{ }^{14}$ Spirometric alterations of all sorts have been described, although overt clinical manifestations are rare. In general, it seems that hyperinflation-or increase in residual volume-is the most frequent abnormality ${ }^{15}$ and it seems to be caused by lymphocyte infiltration of small airway epithelia. ${ }^{16}$ It progresses to interstitial lung fibrosis in $4 \%$ of patients and, very seldom, to a more specific lymphoid interstitial pneumonitis. The pulmonary radiological pattern observed in our patient could have been interpreted as the start of an interstitial disease, but cultures of bronchial specimens and resolution of the infiltrates with antibiotic treatment favoured the diagnosis of bronchopneumonia. Although $H$ influenzae is not a common infectious agent in healthy adults, hosts need not have a predisposing underlying disease. This microorganism produces acute inflammation of the airway mucosa that can occasionally penetrate the bronchial wall and cause a typical bronchopneumonia, as in this case. $^{17}$

On the other hand, respiratory tract dryness impairs clearence of the thickened secretions from the small airways facilitating lung infections in patients with SS. ${ }^{18}$

\section{RENAL INVOLVEMENT}

Renal manifestations of SS can be multiple as shown in table 2. Although membranoproliferative glomerulonephritis has been described $^{20}{ }^{22}$ - and should be considered in the case of rapidly deteriorating renal functionthe main targets of CD4+ cells are tubular epithelia and surrounding interstitium. ${ }^{24}$ The density of lymphoid infiltration correlates with 
Table 2 Renal manifestations of $\operatorname{SS}^{819-23}$

Diabetes insipidus Tubular acidosis Fanconi's syndrome Tubular and interstitial nephritis Nephrocalcinosis Glomerulonephritis Renal pseudolymphoma Renomegalia

Table 3 Treatment of $S S^{43-47}$

Sicca syndrome

Eye drops: carboxymethyl cellulose or artificial substitutes (slow release tears, reservoires and other devices are available)

Sialogues: water, sugar free candies, chewing gums and saliva substitutes

Prevention of dental caries: topical fluoride, and dental plaque control

Lubricant jellies and lotions: mucolytic agents in 5\% acetyl cysteine

Oral bromhexine: improves KCS and possibly xerostomia

Immunoactive drugs: topical CsA, oral interferon alpha

Arthralgia/arthritis

NSAIDs

Chloroquine and hydroxychloroquine

Distal tubular acidosis

Alkali treatment (may be effective in lacrimal and salivary secretions)

Immunosuppressive drugs indications

Life threatening extraglandular disease: in combination with high dose corticosteroids

Azathioprine: probably effective in avoiding progression of interstitial lung disease

Cyclophosphamide: may be effective in sicca symptoms and in tubular acidosis, may increase the risk of lymphoma

Methotrexate: obtains symptomatic relief of general features and exocrine involvement and even osteomalacia, ${ }^{34}$ which can be avoided by preventive treatment with a daily lifelong alkali replacement. In the long term, urolithiasis, along with repetitive urine infections, can lead to a decrease in glomerular filtration rate and to chronic renal failure.

\section{NEONATAL LUPUS}

It is well known that women who have antibodies to Ro or La are at risk of giving birth to children with neonatal lupus, regardless of their clinical disease, with a relative risk of suffering a congenital complete heart block of $500 .{ }^{35}$ This irreversible manifestation is generally detected between 16 and 24 weeks of gestation, and may be associated with myocarditis. $^{3637}$

\section{THERAPEUTIC CONSIDERATIONS}

The natural course of SS is poorly understood because of the absence of markers of disease activity. ${ }^{38}$ The existence of multiple autoantibodies in the sera of the patients is characteristic, but their significance remains unknown. ${ }^{39}$ Although some of them, such as anti-Ro and anti-La antibodies, are pathogenetic for fetus heart, evidence is lacking of their participation in humoral and/or cell mediated immune reactions responsible for tissue damage. ${ }^{7}$ Some patients show raised levels of acute phase proteins, which could reflect cytokine mediation of tissue damage, ${ }^{4}$ but this hypothesis is not completely demonstrated. ANA titres, serum viscosity ${ }^{40}$ and other serological measurement ${ }^{41}$ have been found to correlate with disease activity in several series of patients, but they are not reliable as outcome measures. In fact, in many of these patients lymphoid proliferation remains localised to glands, with sicca syndrome being the sole expression of the diease. ${ }^{42}$

As a result, SS treatment is empirical and symptomatic. It is focused on the relief of the sicca syndrome and other symptoms that accompany the disease rather than seeking remission of the process (table 3). Immunomodulatory drugs are reserved for patients with severe extra-glandular manifestations as it is not known whether they are capable of modifying lymphocytic activation in this condition. ${ }^{48}$

We want to thank Mrs L Gulliksen for editorial assistance.

1 Daniels TE, Silverman S, Michalski JP, Greenspan JS, Silvester RA, Talal N. The oral component of Sjögren's syndrome. Oral Surg Oral Med Oral Pathol 1975;39:87585 .

2 Nishikai M, Akiya K, Tojo T, Onoda N, Tani M, Shimizu K. 'Seronegative' Sjogren's syndrome manifested as a subset of chronic fatigue syndrome. Br J Rheumatol 1996;35: $471-4$.

3 Karsh J, Pavlidids N, Weintraub BD, Moutsopoulos HM. Thyroid disease in Sjögren's syndrome. Arthritis Rheum 1980;23:1326-9.

4 Price EJ, Venables PJW. The etiopathogenesis of Sjögren's syndrome. Semin Arthritis Rheum 1995;25:117-33.

5 Jacobsson LTH, Axell TE, Hansen BU, Henricsson VJ, Larsson A, Lieberkind K, et al. Dry eyes or mouth: an epidemiological study in Swedish adults, with special reference to primary Sjögren's syndrome. J Autoimmunity
$1989 ; 2: 521-7$.

6 Manthorpe R, Asmussen K, Oxholm P. Primary Sjögren's syndrome: Diagnostic criteria, clinical features, and disease activity. J Rheumatol 1997;24 (suppl):8-11.

7 Oxholm P, Asmussen K. Primary Sjögren's syndrome: the challenge for classification of disease manifestations. J Intern Med 1996;239:467-74. 
8 Manthorpe R. Sudden onset unilateral renomegaly as an initial manifestation of primary Sjögren syndrome in a teenage girl. Scand J Rheumatol 1996;25:186-8.

9 Zimhony O, Sthoeger Z, David DB, Khayim YK, Geltner D. Sjögren's syndrome presenting as hypokalemic paralysis due to distal renal tubular acidosis. J Rheumatol 1995;22: 2366-8.

10 Creange A, Laplane D, Habib K, Attal N, Assuerus V. Dementia disclosing primary Gougerot-Sjögren syndrome. Rev Neurol (Paris) 1992;148:376-80.

11 Asmussen K, Andersen V, Bendixen G, Schiodt M, Oxholm P. A new model for classification of disease manifestations in primary Sjögren's syndrome in a retrospective long-term study. J Intern Med 1996;239:475-82.

12 Venables PJW. Overlap syndromes. In: Klippel JH, Dieppe PA, eds. Rheumatology. London:Mosby-Year Book Europe, 1994:28.1-28.8.

13 Newball HH, Brahim SA. Chronic obstructive airway disease in patients with Sjögren's syndrome. Am Rev disease in patients with Sjog

14 Segal I, Fink G, Machtey I, Gura V, Spitzer SA. Pulmonary function abnormalities in Siögren's syndrome and the sicca function abnormalities in Sjögren's

15 Lahdensuo A, Korpela M. Pulmonary findings in patients with primary Sjögren's syndrome. Chest 1995;108:31619.

16 Papiris SA, Maniati M, Constantopoulos SH, Roussos C, Montsopoulos HM, Skopouli FN. Lung involvement in primary Sjogren's syndrome is mainly related to the small airway disease. Ann Rheum Dis 1999;58:61-4.

17 Fraser RG, Paré JAP, Paré PD, Fraser RS, Genereux GP. Diagnosis of diseases of the chest. 3rd ed. Philadelphia: WB Saunders, 1989:853.

18 Fox RI. Sjögren syndrome. In: Kelley WN, Harris ED, Ruddy S, Sledge CB, eds. Textbook of rheumatology. 5 th ed. Philadelphia: WB Saunders, 1997:960.

19 Nagayama Y, Shigeno M, Nakagawa Y, Suganuma A, Takeshita A, Fujiyama K, et al. Acquired nephrogenic diabetes shita A, Fujiyama K, et al. Acquired nephrogenic diabetes insipidus secondary to distal renal tubular acidosis and nephrocalcinosis associated with

20 Talal N, Zisman E, Schur PH. Renal tubular acidosis, glomerulonephritis and immunologic factors in Sjögren's syndrome. Arthritis Rheum 1968;11:774-86.

21 Moutsopoulos HM, Cledes J, Skopouli FN, Elisaf M, Youinou P. Nephrocalcinosis in Sjögren's syndrome: a late sequela of renal tubular acidosis. J Intern Med 1991; 230 187-91.

22 Cortez MS, Sturgill BC, Bolton WK. Membranoproliferarimary Sjögren's syndrome. Am J Kidney Dis 1995;25:632-6.

23 Cacoub P, Ginsburg C, Tazi Z, Beaufils H, Charlotte F, Davi F, et al. Sjögren's syndrome with acute renal failure caused by renal pseudolymphoma. Am J Kidney Dis 1996 ; 28:762-6.

24 Murata H, Kita Y, Sakamoto A, Matsumoto I, Matsumura $\mathrm{R}$, Sugiyama $\mathrm{T}$, et al. Limited TCR repertoire of infiltrating $\mathrm{T}$ cells in the kidneys of Sjögren's syndrome patients with T cells in the kidneys of Sjogren's syndrome patients
interstitial nephritis. J Immunol 1995;155:4084-9.

25 Cohen EP, Bastani B Cohen MR, Kolner S, Hemken P, Gluck SL. Absence of H+-ATPase in cortical collecting Gluck SL. Absence of H+-ATPase in cortical collecting tubules of a patient with Sjogren's syndrome and distal
renal tubular acidosis. J Am Soc Nephrol 1992;3:263-71.

26 Konishi K, Hayashi M, Saruta T. Renal tubular acidosis with autoantibody directed to renal collecting duct cells. N Engl J Med 1994;331:1593-4

27 Shearn MA, Tu WH. Latent renal tubular acidosis in Sjögren's syndrome. Ann Rheum Dis 1968;27:27-32.

28 Winer RL. Sjögren's syndrome. In: Grisham E, Churg J, Needle MA, Venkataseshan VS, eds. The kidney in collagen vascular diseases. New York: Raven Press, 1993:179-87.
29 Eriksson P, Denneberg T, Larsson L, Lindström F. Biochemical markers of renal disease in primary Sjögren's syndrome. Scand J Urol Nephrol 1995;29:383-92.

30 Eriksson P, Denneberg T, Lundström I, Skogh T, Tiselius HG. Autoantibodies and primary Sjögren's syndrome in a hypocitraturic stone population. Scand J Urol Nephrol 1997;31:73-80

31 Eriksson P, Denneberg T, Eneström S, Johansson B, Lindström F, Skogh T. Urolithiasis and distal renal tubular acidosis preceding primary Sjögren's sydrome: a retrospective study $5-53$ years after the presentation of urolithiasis. J Intern Med 1996;239:483-8.

32 Eneström S, Denneberg T, Eriksson P. Histopathology of renal biopsies with correlation to clinical findings in primary Sjögren's syndrome. Clin Exp Rheumatol 1995; 13:697-703.

33 Poux JM, Peyronnet P, Le Meur Y, Favereau JP, Charmes JP, Leroux-Robert C. Hypokalemic quadriplegia and respiratory arrest revealing primary Sjögren's sydrome. Clin Nephrol 1992;37:189-91.

34 Aerts J, Vigouroux C, Fournier P, Cariou D, Pasquier P. Osteomalacia of renal origin disclosing Gougerot-Sjögren syndrome. Rev Med Intern 1994;15:43-7.

35 Manthorpe T, Manthorpe R. Congenital complete heart block in children of mothers with primary Sjögren's syndrome. Lancet 1992;340:1359-60.

36 Buyon JP, Waltuck J, Kleinman C, Copel J. In utero identification and therapy of congenital heart block. Lupus 1995;4:116-21

37 Buyon JP, Swersky S, Fox H, Bierman F, Winchester R. Intra-uterine therapy of presumptive fetal myocarditis with heart block occurring in a mother with systemic lupus erythematosus and a predominance of $\mathrm{La}(\mathrm{SSB})$ antibodies. Arthritis Rheum 1987;40:44-9.

38 Manthorpe R, Jacobsson LT. Sjögren's syndrome. Baillieres Clin Rheumatol 1995;9:483-96.

39 Fox RI, Maruyama T. Pathogenesis and treatment of Sjögren's syndrome. Curr Opin Rheumatol 1997;9:393-9.

40 Lossjev GM, Khodarev NV, Vassiliev VI, Nassonova VA. Serum viscosity is a sensitive test for monitoring primary Sjögren syndrome. Int J Tissue React 1993;15·215-18.

41 Fox RI. Sjögren's syndrome. Controversies and progress. Clin Lab Med 1997;17:431-4.

42 Humphreys-Beher MG, Brayer J, Yamachika S, Peck AB, Jonsson R. An alternative perspective to the immune response in autoimmune exocrinopathy: induction of functional quiescence rather than destructive autoaggression. Scand J Immunol 1999;49:7-10.

43 Williams DL. A comparative approach to topical cyclosporine therapy. Eye 1997;11:453-64.

44 Deheinzelin D, Capelozzi VL, Kairalla RA, Barbas JV, Saldiva PH, Carvalho CR. Interstitial lung disease in primary Sjögren's sydrome. Clinical-pathological evaluation and response to treatment. Am J Respir Crit Care Med 1996;154:794-9.

45 Skopouli FN, Jagiello P, Tsifetaki N, Moutsopoulos HM. Methotrexate in primary Sjogren's syndrome. Clin Exp Rheumatol 1996;14:555-8.

46 Price EJ, Rigby SP, Clancy U, Venables PJW. A double blind placebo controlled trial of azathioprine in the treatment of placebo controlled trial of azathioprine in the treatment of
primary Sjögren's syndrome. J Rheumatol 1998;25:896-9.

47 Kruize AA, Hene RJ, Kallenberg CG, Van Bijsterveld OP, Van Der Heide A, Kater L, et al. Hydroxychloroquine treatment for primary Sjögren's syndrome: a two year double blind crossover trial. Ann Rheum Dis 1993;52:360-4.

48 Manthorpe R, Prause JU. Treatment of Sjögren's syndrome: an overview (review). Scand J Rheumatol 1986; suppl $61: 237-41$ 